\title{
Preparation of Rabri from Stored Concentrated Fig (Ficus carica L.) Pulp
}

\author{
C.Y. Dhumal ${ }^{1 *}$, J.K. Dhemre ${ }^{1}$, R.J. Desale ${ }^{2}$, M.B. Shete ${ }^{3}$ and S.N. Ambad ${ }^{4}$ \\ ${ }^{1}$ Department of Horticulture, Rahuri, Maharashtra, India \\ ${ }^{2}$ Department of Animal Husbandry and Dairy Science, Rahuri, Maharashtra, India \\ ${ }^{3}$ Floricultarist, NARP, Plain Zone, Ganeshkhind, Pune, Maharashtra, India \\ ${ }^{4}$ Horticulture Section, College of Agriculture, Kolhapur, Maharashtra, India
}

*Corresponding author

A B S T R A C T

\begin{tabular}{|l|}
\hline K e y w o r d s \\
$\begin{array}{l}\text { Fig, concentrated fig } \\
\text { pulp, rabri, Sensory } \\
\text { parameters, Cost of } \\
\text { production }\end{array}$ \\
\hline Article Info \\
\hline $\begin{array}{l}\text { Accepted: } \\
\text { 23 March } 2018 \\
\text { Available Online: } \\
\text { 10 April } 2018\end{array}$ \\
\hline
\end{tabular}

The present investigation entitled "Preparation of rabri from stored concentrated fig (Ficus carica L.) pulp" was carried out during 2015-2016 at Post Harvest Technology Centre, Department of Horticulture, Mahatma Phule Krishi Vidyapeeth, Rahuri. The standardization of recipe i.e. quantity of concentrated fig pulp and sweetened condensed milk was finalised on the basis of sensory evaluation as $150 \mathrm{~g}$ and $1 \mathrm{~L}$, respectively. The concentrated fig pulp which was packed in different packaging materials (glass bottles and standy pouches) and stored at two different storage conditions (ambient temperature and cold storage) for a period of 180 days were used for preparation of fresh rabri every month. On the basis of sensory evaluation, concentrated fig pulp packed in glass bottles and stored in cold storage was found to be best treatment combination for preparation of rabri during 180 days of storage. The cost of preparation of best treatment of rabri prepared from concentrated fig pulp was Rs. $237.81 / \mathrm{kg}$.

\section{Introduction}

Fig (Ficus carica L.) belongs to the family Moraceae and native of Southern Arabia is widely cultivated throughout the tropical and subtropical regions of the world and to some extent in moderate climatic regions of temperate zone.

It is one of the most salt and drought tolerant fruit crops. It is grown commercially in areas bordering the Mediterranean sea, as well as U.S.A. In India, its commercial production is limited to a few centres in Maharashtra and South India. It is cultivated on commercial scale in adjoining areas of Pune and Aurangabad. It is grown in small patches in Bengaluru, Sreerangapattanam and Bellary districts of Karnataka. It is also grown in and around Anantpur and Hyderabad in Telangana. In northern parts of India, its cultivation is scattered as a homestead crop in Punjab, Bihar, West Bengal and Uttar Pradesh. The production of fig in Maharashtra for the year 2013-14 was 2,705 MT from an area of 947 ha (Anon., 2014). Fig fruits cannot be stored for longer period and have to be sold in local market immediately after harvest. If the fruits are preserved in the form of concentrated pulp during seasonal glut, it may 
help in better utilization of fig fruits for preparation of different types of products. Until recently, the surplus milk in flush season has been converted into skim milk powder and ghee by most of the dairies. The skim milk powder is largely used for recombination purpose during lean season. Now, we are fast moving from an area of scarcity to that of plenty. Thus the demand of skim milk powder and ghee is decreasing. Our dairy industry, therefore, may have to change the strategy that is, from skim milk powder to value added products like khoa, rabri, burfi, kalakand, etc. Rabri is indigenous milk product.

It is concentrated and sweetened whole milk product containing several layers of clotted cream. The basic methodology denotes to fresh cream milk heated in boiling pan to boil it. A thin layer of clotted cream formed on surface of milk clotted from time to time using a wooden stick. These layers of clotted cream are placed one over the other. This process is continued till $1 / 6^{\text {th }}$ of original milk is left. Sugar 5 to $6 \%$ by weight of original milk volume is added. Fruits like grapes, apples, custard apple, etc. could be utilized for the preparation of fruit rabri. In addition, the colour and flavour of rabri is improved by incorporation of fruit pulp (Kerawala and Sidappa, 1963). Fig is a seasonal crop and its demand for utilization in various milk based products like burfi, ice cream, milkshake, etc. is rising. Therefore, the present investigation was carried out with an aim to utilize the stored concentrated fig pulp in rabri preparation with the following objectives

To standardize the recipe for making fig rabri from concentrated fig pulp.

To evaluate the sensory parameters of rabri prepared from concentrated fig pulp.

To study the cost of production of rabri from stored concentrated fig pulp.

\section{Materials and Methods}

\section{Fig fruits and other ingredients}

Fig fruits of $\mathrm{Cv}$. Poona fig were obtained from All India Coordinated Research Project on Arid Zone Fruit Project, Department of Horticulture, MPKV, Rahuri. Well matured fruits of uniform and medium size were harvested, and brought to the Post Harvest Technology Centre for pulp extraction. Sodium benzoate was used as a preservative obtained from manufactures $\mathrm{M} / \mathrm{s}$. Thermo Fisher Scientific India Pvt. Ltd., Mumbai and the sweetened condensed milk (TSS: $\left.60^{\circ} \mathrm{B}\right)$ of popular co-operative brand AMUL (Anand Milk Union Limited, Anand; Gujarat) was used for rabri preparation. It was procured from Ahmednagar city.

\section{Pulp extraction, packaging and storage}

The pulp after extraction from screw type pulper was heated till the TSS of the product became $35^{\circ} \mathrm{B}$. The preservative i.e. sodium benzoate was added before TSS reached to end point. The hot concentrated fig pulp was filled in pre-sterilized $500 \mathrm{~g}$ glass bottles and $200 \mathrm{~mL}$ capacity standy pouches and sealed. All the packed samples were sterilized. The concentrated fig pulp was stored at ambient conditions and cold storage for a period of 180 days. The treatment details are given in Table 1. The flowchart for extraction and storage of concentrated fig pulp is given in Figure 1.

\section{Observation recorded}

\section{Sensory evaluation of rabri}

The sensory evaluation of freshly prepared rabri from stored concentrated fig pulp was done at 30 days interval for a period of 180 days for colour, flavour, texture, taste and overall acceptability by using a 9-point hedonic scale given by Amerine et al., (1979). 


\section{Statistical analysis}

The experiment was planned and carried out using Factorial Completely Randomised Design with five replications. The data obtained in the present investigation for sensory evaluation of rabri prepared from stored concentrated fig pulp was analysed for statistical significance according to the standard procedure given by Panse and Sukatme (1985).

\section{Cost of production}

The cost of production of fig rabri was worked according to the standard procedure given by Lal et al., (1980).

\section{Results and Discussion}

Standardization of recipe for making rabri from concentrated fig pulp

Preliminary trials were conducted for preparation of rabri from concentrated fig pulp. The details of various treatment combinations for the preparation of rabri from different concentrated fig pulp levels are given in Table 2.

From the given treatment combinations, the best treatment was selected using sensory evaluation and used for further research. The flow chart for preparation of fig rabri from concentrated fig pulp is given in Figure 2.

\section{Results of standardized treatments for preparation of rabri from concentrated fig pulp}

The results in the table mentioned hereunder contain the sensory scores of preliminary trials for standardization of recipe for preparation of rabri using different combinations of concentrated fig pulp. The sensory scores of rabri prepared from different combinations of concentrated fig pulp are mentioned in Table 3. On the basis of sensory evaluation, Treatment T5 i.e. $150 \mathrm{~g}$ of concentrated fig pulp and 1 litre of sweetened condensed milk was found to be better having overall acceptability of 8.65 . Hence, the treatment T5 from Table 3 was selected and finalized for further research.

\section{Preparation of rabri from concentrated fig pulp}

The rabri was prepared from concentrated fig pulp packed in glass bottles and standy pouches stored in ambient temperature and cold storage. The rabri from concentrated fig pulp was prepared using standardized treatment i.e., concentrated fig pulp $150 \mathrm{~g}+$ 1.0 litre sweetened condensed milk. The freshly prepared fig rabri every month was evaluated for sensory parameters viz., colour, flavour, texture, taste and overall acceptability.

\section{Sensory parameters of freshly prepared rabri from concentrated fig pulp}

The freshly prepared rabri from concentrated fig pulp had score for colour, flavour, texture, taste and overall acceptability as 8.74, 8.50, $8.52,8.65$ and 8.60 , respectively.

Sensory parameters of freshly prepared rabri from stored concentrated fig pulp during 180 days

\section{Colour}

The treatment combination of packaging materials and storage conditions indicated that the colour of rabri prepared from concentrated fig pulp was found to be statistically significant upto 180 days. The highest sensory score for colour was observed in P1S2 from 8.70 to 8.12 followed by P2S2 from 8.65 to 8.02 during 180 days of storage (Table 4 ). 
Fig.1 Preparation of concentrated fig pulp

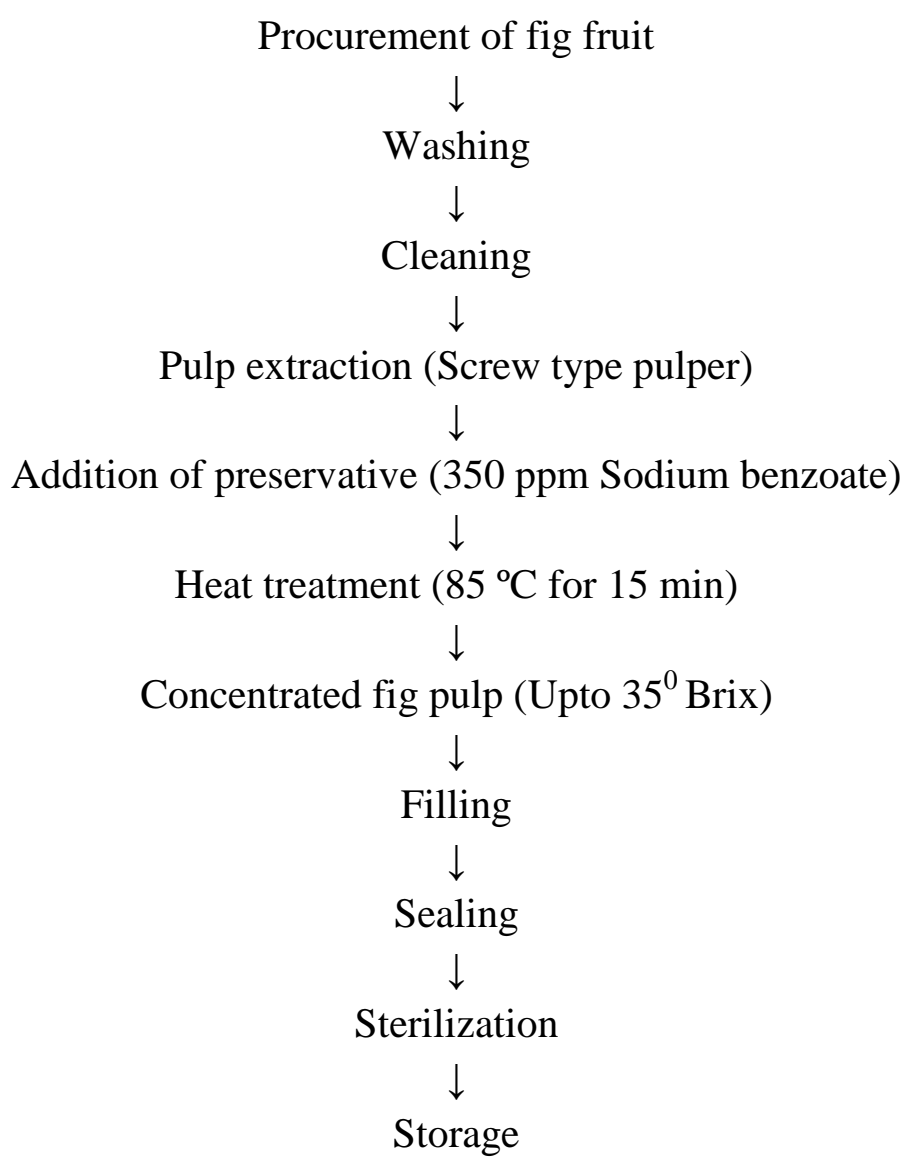

Fig.2 Preparation of fig rabri from concentrated fig pulp

Sweetened condensed milk

$\downarrow$

Addition of concentrated fig pulp

$\downarrow$

Mix well

$\downarrow$

Filling

$\downarrow$

Sealing

$\downarrow$

Rabri 
Table.1 Treatment details for concentrated fig pulp storage

\begin{tabular}{c|c|l|}
$\begin{array}{c}\text { Treatment } \\
\text { No. }\end{array}$ & Interaction & \multicolumn{1}{|c|}{ Treatment details } \\
\hline T1 & P1S1 & $\begin{array}{l}\text { Concentrated fig pulp + Glass bottles + Ambient } \\
\text { conditions. }\end{array}$ \\
\hline T2 & P2S1 & $\begin{array}{l}\text { Concentrated fig pulp + Standy pouch + Ambient } \\
\text { conditions }\end{array}$ \\
\hline T3 & P1S2 & $\begin{array}{l}\text { Concentrated fig pulp + Glass bottles + Cold storage } \\
\text { Concentrated fig pulp + Standy pouch + Cold storage }\end{array}$ \\
\hline T4 & P2S2 & Conch \\
\hline
\end{tabular}

Table.2 Treatment details for rabri prepared from concentrated fig pulp

\begin{tabular}{|c|c|c|}
\hline Treatments & $\begin{array}{c}\text { Concentrated Fig pulp } \\
\mathbf{3 5}^{\mathbf{0}} \mathbf{B} \mathbf{( g )}\end{array}$ & $\begin{array}{c}\text { Sweetened Condensed milk } \\
\text { (litres) }\end{array}$ \\
\hline $\mathbf{T} 1$ & 125 & 0.750 \\
\hline T2 & 125 & 1.000 \\
\hline T3 & 125 & 1.250 \\
\hline T4 & 150 & 0.750 \\
\hline T5 & 150 & 1.000 \\
\hline T6 & 150 & 1.250 \\
\hline T7 & 175 & 0.750 \\
\hline T8 & 175 & 1.000 \\
\hline T9 & 175 & 1.250 \\
\hline
\end{tabular}

Table.3 Sensory scores of preliminary trials for rabri prepared from various treatment combinations of concentrated fig pulp

\begin{tabular}{|c|c|c|c|c|c|c|}
\hline $\begin{array}{c}\text { Sr. } \\
\text { No. }\end{array}$ & Treatments & Colour & Flavour & Texture & Taste & $\begin{array}{c}\text { Overall } \\
\text { Acceptability }\end{array}$ \\
\hline $\mathbf{1}$ & $\mathbf{T 1}$ & 8.05 & 7.95 & 7.90 & 8.34 & 8.06 \\
\hline $\mathbf{2}$ & $\mathbf{T 2}$ & 8.11 & 8.08 & 7.84 & 8.41 & 8.11 \\
\hline $\mathbf{3}$ & $\mathbf{T 3}$ & 8.17 & 8.10 & 7.96 & 8.27 & 8.13 \\
\hline $\mathbf{4}$ & $\mathbf{T 4}$ & 8.62 & 8.41 & 8.38 & 8.56 & 8.49 \\
\hline $\mathbf{5}$ & $\mathbf{T 5}$ & 8.78 & 8.52 & 8.56 & 8.72 & 8.65 \\
\hline $\mathbf{6}$ & $\mathbf{T 6}$ & 8.59 & 8.33 & 8.41 & 8.66 & 8.50 \\
\hline $\mathbf{7}$ & $\mathbf{T 7}$ & 8.23 & 8.09 & 8.00 & 8.16 & 8.12 \\
\hline $\mathbf{8}$ & $\mathbf{T}$ & 8.10 & 8.02 & 8.12 & 8.28 & 8.13 \\
\hline $\mathbf{9}$ & $\mathbf{T 9}$ & 8.23 & 7.96 & 8.09 & 8.31 & 8.15 \\
\hline
\end{tabular}


Table.4 Effect of packaging materials and storage conditions on sensory parameters of fresh rabri prepared from stored concentrated fig pulp

\begin{tabular}{|c|c|c|c|c|c|c|c|c|}
\hline Particulars & Storage period (days) & P1S1 & P2S1 & P1S2 & P2S2 & SE. $\mathbf{m}( \pm)$ & CD@ $9 \%$ & CD@ $1 \%$ \\
\hline \multicolumn{9}{|l|}{ Colour } \\
\hline & 30 days & 8.59 & 8.35 & 8.70 & 8.65 & 0.0367 & 0.1132 & 0.1587 \\
\hline & 60 days & 8.45 & 8.25 & 8.61 & 8.55 & 0.0265 & 0.0818 & 0.1146 \\
\hline & 90 days & 8.30 & 8.12 & 8.52 & 8.43 & 0.0163 & 0.0503 & 0.0705 \\
\hline & 120 days & 8.16 & 7.98 & 8.40 & 8.31 & 0.0155 & 0.0478 & 0.0670 \\
\hline & 150 days & 8.07 & 7.85 & 8.25 & 8.18 & 0.0176 & 0.0541 & 0.0758 \\
\hline & 180 days & 7.95 & 7.70 & 8.12 & 8.02 & 0.0118 & 0.0365 & 0.0511 \\
\hline \multicolumn{9}{|l|}{ Flavour } \\
\hline & 30 days & 8.30 & 8.09 & 8.44 & 8.38 & 0.0327 & 0.1006 & 0.1411 \\
\hline & 60 days & 8.19 & 7.95 & 8.38 & 8.30 & 0.0306 & 0.0943 & 0.1323 \\
\hline & 90 days & 8.06 & 7.85 & 8.22 & 8.15 & 0.0163 & 0.0503 & 0.0705 \\
\hline & 120 days & 7.90 & 7.70 & 8.10 & 8.03 & 0.0176 & 0.0541 & 0.0758 \\
\hline & 150 days & 7.78 & 7.60 & 8.00 & 7.90 & 0.0135 & 0.0415 & 0.0582 \\
\hline & 180 days & 7.65 & 7.54 & 7.85 & 7.80 & 0.0114 & 0.0352 & 0.0494 \\
\hline \multirow{2}{*}{\multicolumn{9}{|c|}{ Texture }} \\
\hline & & & & & & & & \\
\hline & 60 days & 8.20 & 8.01 & 8.41 & 8.35 & 0.0257 & 0.0793 & 0.1111 \\
\hline & 90 days & 8.05 & 7.85 & 8.30 & 8.22 & 0.0204 & 0.0629 & 0.0882 \\
\hline & 120 days & 7.88 & 7.70 & 8.18 & 8.08 & 0.0167 & 0.0516 & 0.0723 \\
\hline & 150 days & 7.72 & 7.52 & 8.02 & 7.90 & 0.0143 & 0.044 & 0.0617 \\
\hline & 180 days & 7.58 & 7.35 & 7.91 & 7.77 & 0.0122 & 0.0377 & 0.0529 \\
\hline \multicolumn{9}{|l|}{ Taste } \\
\hline & 30 days & 8.51 & 8.29 & 8.61 & 8.57 & 0.0408 & 0.1258 & 0.1764 \\
\hline & 60 days & 8.40 & 8.18 & 8.55 & 8.50 & 0.0367 & 0.1132 & 0.1587 \\
\hline & 90 days & 8.28 & 8.10 & 8.45 & 8.38 & 0.0245 & 0.0755 & 0.1058 \\
\hline & 120 days & 8.14 & 7.95 & 8.36 & 8.26 & 0.0204 & 0.0629 & 0.0882 \\
\hline & 150 days & 7.98 & 7.75 & 8.27 & 8.14 & 0.0184 & 0.0566 & 0.0794 \\
\hline & 180 days & 7.81 & 7.62 & 8.13 & 8.00 & 0.0149 & 0.0459 & 0.0644 \\
\hline \multicolumn{9}{|c|}{ Overall acceptability } \\
\hline & 30 days & 8.43 & 8.22 & 8.56 & 8.51 & 0.0245 & 0.0755 & 0.1058 \\
\hline & 60 days & 8.31 & 8.10 & 8.49 & 8.43 & 0.0327 & 0.1006 & 0.1411 \\
\hline & 90 days & 8.17 & 7.98 & 8.37 & 8.30 & 0.0147 & 0.0453 & 0.0635 \\
\hline & 120 days & 8.02 & 7.83 & 8.26 & 8.17 & 0.0171 & 0.0528 & 0.0741 \\
\hline & 150 days & 7.89 & 7.68 & 8.14 & 8.03 & 0.0163 & 0.0503 & 0.0705 \\
\hline & 180 days & 7.75 & 7.55 & 8.00 & 7.90 & 0.0114 & 0.0352 & 0.0494 \\
\hline
\end{tabular}


Table.5 Economics of the cost of production of fig rabri from concentrated fig pulp

\begin{tabular}{|c|c|c|c|c|c|c|c|c|c|c|}
\hline \multirow{2}{*}{$\begin{array}{l}\text { Sr. } \\
\text { No. }\end{array}$} & \multirow[t]{2}{*}{ Particulars } & \multirow{2}{*}{$\begin{array}{l}\text { Rate } \\
\text { (Rs.) }\end{array}$} & \multicolumn{2}{|c|}{ P1S1 } & \multicolumn{2}{|c|}{ P2S1 } & \multicolumn{2}{|c|}{ P1S2 } & \multicolumn{2}{|c|}{ P2S2 } \\
\hline & & & Qty. & $\begin{array}{l}\text { Cost } \\
\text { (Rs.) }\end{array}$ & Qty. & $\begin{array}{l}\text { Cost } \\
\text { (Rs.) }\end{array}$ & Qty. & $\begin{array}{l}\text { Cost } \\
\text { (Rs.) }\end{array}$ & Qty. & $\begin{array}{l}\text { Cost } \\
\text { (Rs.) }\end{array}$ \\
\hline A. & Fixed cost & & & & & & & & & \\
\hline 1. & Interest @12 per cent on fixed assets. & -------- & ----- & 0.015 & ----- & 0.015 & ----- & 0.015 & ------ & 0.015 \\
\hline 2. & Depreciation@10 per cent on fixed assets. & -------- & ------ & 0.013 & ------ & 0.013 & ------ & 0.013 & ------ & 0.013 \\
\hline & Total fixed cost (Rs.) & & & 0.028 & & 0.028 & ------ & 0.028 & ------ & 0.028 \\
\hline B. & Variable cost & & & & & & & & & \\
\hline 1. & Fig fruits & $40 / \mathrm{kg}$ & $260 \mathrm{~g}$. & 10.4 & $260 \mathrm{~g}$. & 10.4 & $260 \mathrm{~g}$. & 10.4 & $260 \mathrm{~g}$. & 10.4 \\
\hline 2. & Recovery of concentrated pulp & & $150 \mathrm{~g}$. & ----- & $150 \mathrm{~g}$. & ---- & $150 \mathrm{~g}$. & ---- & $150 \mathrm{~g}$. & ----- \\
\hline 3. & Preservative (Sodium Benzoate) & $1000 / \mathrm{kg}$ & $\begin{array}{c}0.91 \\
\text { g. }\end{array}$ & 0.91 & $\begin{array}{c}0.91 \\
\text { g. }\end{array}$ & 0.91 & $\begin{array}{c}0.91 \\
\text { g. }\end{array}$ & 0.91 & $\begin{array}{c}0.91 \\
\text { g. }\end{array}$ & 0.91 \\
\hline 4. & Packaging & $\begin{array}{c}\text { Rs. 12/ glass } \\
\text { jar. } \\
\text { Rs } 1.60 / \\
\text { Standee pouch }\end{array}$ & 1 & 12 & 1 & 1.60 & 1 & 12 & 1 & 1.60 \\
\hline 5. & Storage (Cold storage) & Rs. $2 / \mathrm{kg}$ & ------- & -------- & ------- & -------- & $\begin{array}{c}150 \\
\text { g. }\end{array}$ & 0.30 & $150 \mathrm{~g}$. & 0.30 \\
\hline$\overline{6 .}$ & Milk (sweetened condensed & $\begin{array}{c}90 / \mathrm{can} \\
(400 \mathrm{ml} .)\end{array}$ & 11 & $225 / 1$ & 11. & $225 / 1$ & 11. & $225 / 1$ & 11. & $225 / 1$ \\
\hline 7. & Overhead charges (@10\%)) & -------- & ----- & 24.81 & ------ & 23.79 & ------ & 24.86 & ------ & 23.82 \\
\hline & Total variable cost (Rs.) & & & 273.12 & & 261.70 & & 273.47 & & 262.03 \\
\hline C. & $\begin{array}{l}\text { Total cost }(A+B) \\
(\text { Rs. })\end{array}$ & & & 273.14 & & 261.72 & & 273.49 & & 262.05 \\
\hline D. & Total expenditure (Rs.) & & & 273.14 & & 261.72 & & 273.49 & & 262.05 \\
\hline E. & Total rabri prepared (kg.) & & 1.150 & & 1.150 & & 1.150 & & 1.150 & \\
\hline F. & Cost of production of rabri per kg. & & & 237.51 & & 227.58 & & 237.81 & & 227.86 \\
\hline G. & $\begin{array}{l}\text { Selling Price } \\
\text { (Taking into consideration profit @ 20\%) }\end{array}$ & & $1 \mathrm{~kg}$. & 285.01 & $1 \mathrm{~kg}$. & 273.09 & $1 \mathrm{~kg}$. & 285.40 & $1 \mathrm{~kg}$ & 273.43 \\
\hline
\end{tabular}


The lowest sensory score for colour was observed in P2S1 from 8.35 to 7.70 followed by P1S1 from 8.59 to 7.95 during 180 days. The data indicates that the scores for colour decreased continuously during 180 days. This might be due to non-enzymatic reaction of organic acids with sugars or oxidation of phenols, which leads to formation of brown pigments in the concentrated fig pulp during storage.

Similar results were reported by Kamble (2010) and Sutar (2014) on fig burfi: Kolape (2009) on papaya pulp shrikhand; Kamble et al., (2010) on pineapple burfi; Hinwar (2013) on guava pulp shrikhand and Deshmukh (2014) on custard apple pulp utilisation in icecream and milkshake.

\section{Flavour}

The treatment combination of packaging materials and storage conditions indicated that the flavour of rabri prepared from concentrated fig pulp was found to be statistically significant upto 180 days. The highest sensory score for flavour was observed in P1S2 from 8.44 to 7.85 followed by P2S2 from 8.38 to 7.80 during 180 days of storage. The lowest sensory score for flavour was observed in P2S1 from 8.09 to 7.54 followed by P1S1 from 7.30 to 7.65 during 180 days.

With the increase in storage period there was decrease in the scores for flavour of rabri which might be due to loss of flavouring compounds at a higher rate at higher storage temperature in the concentrated fig pulp during storage. Similar results were reported by Kamble (2010) and Sutar (2014) on fig burfi: Kolape (2009) on papaya pulp shrikhand; Kamble et al., (2010) on pineapple burfi; Hinwar (2013) on guava pulp shrikhand and Deshmukh (2014) on custard apple pulp utilisation in ice-cream and milkshake.

\section{Texture}

The treatment combination of packaging materials and storage conditions indicated that the texture of rabri prepared from concentrated fig pulp was found to be statistically significant upto 180 days. The highest sensory score for texture was observed in P1S2 from 8.48 to 7.91 followed by P2S2 from 8.43 to 7.77 during 180 days of storage. The lowest sensory score for texture was observed in P2S1 from 8.13 to 7.35 followed by P1S1 from 8.31 to 7.58 during 180 days. Similar results were reported by Kamble (2010) and Sutar (2014) on fig burfi: Kolape (2009) on papaya pulp shrikhand; Kamble et al., (2010) on pineapple burfi; Hinwar (2013) on guava pulp shrikhand and Deshmukh (2014) on custard apple pulp utilisation in ice-cream and milkshake.

\section{Taste}

The treatment combination of packaging materials and storage conditions indicated that the taste of rabri prepared from concentrated fig pulp was found to be statistically significant upto 180 days of storage. The highest sensory score for taste was observed in P1S2 from 8.61 to 8.13 followed by P2S2 from 8.57 to 8.00 during 180 days. The lowest sensory score for taste was observed in P2S1 from 8.29 to 7.62 followed by P1S1 from 8.51 to 7.81 during 180 days. From the data it was observed that the taste scores of rabri decreased gradually during 180 days of storage which might be due to the gradual loss in taste scores might be due to changes in the volatile compounds in the concentrated fig pulp during storage. Similar results were reported by Kamble (2010) and Sutar (2014) on fig burfi: Kolape (2009) on papaya pulp shrikhand; Kamble et al., (2010) on pineapple burfi; Hinwar (2013) on guava pulp shrikhand and Deshmukh (2014) on custard apple pulp utilisation in ice-cream and milkshake. 


\section{Overall acceptability}

The treatment combination of packaging materials and storage conditions indicated that the overall acceptability of rabri prepared from concentrated fig pulp was found to be statistically significant upto 180 days.

The highest sensory score for overall acceptability was observed in P1S2 from 8.56 to 8.00 followed by P2S2 from 8.51 to 7.90 during 180 days of storage. The lowest sensory score for overall acceptability was observed in P2S1 from 8.22 to 7.55 followed by P1S1 from 8.43 to 7.75 during 180 days. From the data it is observed that that the overall acceptability scores of rabri decreased due to oxidation, storage time, temperature, light exposure, packaging materials sorption or chemical composition and changes in volatile compounds in the concentrated fig pulp during storage. Similar results were reported by Kamble (2010) and Sutar (2014) on fig burfi: Kolape (2009) on papaya pulp shrikhand; Kamble et al., (2010) on pineapple burfi; Hinwar (2013) on guava pulp shrikhand and Deshmukh (2014) on custard apple pulp utilisation in ice-cream and milkshake.

\section{Economics of preparation of rabri from concentrated fig pulp}

The cost of production of rabri from concentrated fig pulp which had maximum overall acceptability was from treatment P1S2 which is Rs. 237.81/kg (Table 5). Similar results are reported by Kamble (2010) on fig burfi; Sakate (2000) on wood apple burfi; Yadav et al., (2010) on custard apple icecream; Bankar et al., (2012) on pineapple burfi; Khore (2013) on strawberry lassi; Hinwar (2013) on guava pulp based shrikhand; Deshmukh (2014) on custard apple ice-cream and milkshake; Patil et al., (2014) on papaya ice-cream; Navale et al., (2015) on wood apple burfi.
The standardization of recipe i.e. quantity of concentrated fig pulp (150 g) and sweetened condensed milk $(1 \mathrm{~L})$ was finalised on the basis of sensory evaluation. The concentrated fig pulp packed in different packaging materials (glass bottles and standy pouches) and stored at two different storage conditions (ambient temperature and cold storage) for a period of 180 days were used for preparation of fresh rabri every month. On the basis of sensory evaluation, concentrated fig pulp packed in glass bottles and stored in cold storage was found to be best treatment combination for preparation of rabri during 180 days of storage. The cost of preparation of best treatment of rabri prepared from concentrated fig pulp was Rs. $237.81 / \mathrm{kg}$.

\section{References}

Amerine, M.A., Pangborn, R.M. and Roesseler, E.B. 1973. Principles of sensory evaluation of Food. Academic Press. New York.

Anonymous. 2014. National Horticulture Mission Database, 2013- 2014.

Bankar, S.N. Barbind, R.P. Korake, R.L. Gaikwad S.V. and Bhutkar, S.S. 2012. Studies on preparation of pineapple burfi. Asian Journal of Dairy and Food Research, 32 (1): 40-45.

Deshmukh, S.S. 2014. Studies on utilisation of custard apple pulp for preparation of ice-cream and milkshake. M.Sc. (Agri.) thesis, MPKV, Rahuri, Maharashtra, India.

Hinwar, D.H. 2013. Preparation of shrikhand by using guava pulp. M.Sc. (Agri.) thesis, MPKV, Rahuri, Maharashtra, India.

Kamble K., Kahate, P.A. Chavan S.D. and Thakare. V.M. 2010. Effect of Pineapple Pulp on Sensory and Chemical Properties of Burfi, Veterinary World. 3(7): 329-331. 
Kamble, D.K. 2010. Standardization of technique for preparation of fig burfi. Ph.D. (Agri.) thesis, MPKV, Rahuri, Maharashtra, India.

Kerawala, D.N. and Sidappa, G.S. 1963. Indian research on mango toffee. Indian Sugar, 14 (3):19- 20.

Khore, N.C. 2013. Preparation of strawberry lassi. M.Sc. (Agri.) thesis, MPKV, Rahuri, Maharashtra, India.

Kolape, R.H. 2009. Use of papaya pulp in shrikhand preparation. M.Sc. (Agri.) thesis, MPKV, Rahuri, Maharashtra, India.

Lal, M., Agarwal, S.B. and Nambudripad, V.K.N. 1980. Evaluation and cost structure of fruit youghurt. Indian dairyman, 32(6): 488-492.

Navale, A.S. Deshmukh, B.R. Korake, R.L. Narwade, S.G. Mule. P.R. 2015. Production profile, proximate composition, sensory evaluation and cost configuration of wood apple burfi.
Animal Science Reporter, 8(3): 718724.

Panse, V.S. and Sukhatme, P.V. 1985 Statistical methods for agricultural workers. I.C.A.R. New Delhi.

Patil, S. P. Zinjarde R. M. and Rodke. S. N. 2014. Effect of Different Levels of Papaya (Carica papaya) Pulp on Quality of Ice-cream. PDKV Res. J., 38 (1):212-218.

Sakate, R.J. 2000. Studies on preparation of wood apple burfi. M.Sc. (Agri.) thesis, MPKV, Rahuri, Maharashtra, India.

Sutar, S.A. 2014. Effect of Modified atmospheric packaging on the shelf life of fig burfi. M.Sc. (Agri.) thesis, MPKV, Rahuri, Maharashtra, India.

Yadav, C.M. Karanjkar L.M. and Kashid U.B., 2010. Effect of assimilation of custard apple (Annona squamosa) pulp on chemical quality and cost of icecream. Journal of Dairying Foods and Husbandry Science, 29(2): 86 - 91.

\section{How to cite this article:}

Dhumal, C.Y., J.K. Dhemre, R.J. Desale, M.B. Shete and Ambad, S.N. 2018. Preparation of Rabri from Stored Concentrated Fig (Ficus carica L.) Pulp. Int.J.Curr.Microbiol.App.Sci. 7(04): 3005-3014. doi: https://doi.org/10.20546/ijcmas.2018.704.340 